\title{
The effects of student-centered teaching methods used in mathematics courses on mathematics achievement, attitude, and anxiety: a meta-analysis study \\ Elif Ay Emanet \\ Ministry of National Education, Kocaeli, Turkey \\ ORCID: 0000-0003-4960-5476
}

\author{
Fatih Kezer* \\ Department of Measurement and Evaluation, Kocaeli University, Kocaeli, Turkey \\ ORCID: 0000-0001-9640-3004
}

\section{Article history \\ Received: \\ 30.05.2020 15.11.2020 \\ Accepted: \\ 21.11.2020 \\ Key words: \\ Meta-analysis, \\ Mathematics, \\ Achievement, \\ Attitude, \\ Anxiety.}

Received in revised form:
Mathematics is a branch of science that is used to understand and explore the relationship between the parts that make a great structure or a whole, the cause-and-effect relationships between the parts and the whole, all natural phenomena and, life in short. Students in Math must make progress in learning to follow teacher's instructions and participating actively, using prior knowledge, building on it, and making sense of it instead of memorizing. Since student-centered teaching methods have frequently ben used in the curriculum in recent years, the aim of the research is to examine the results of them and to shed a light on future generations. In the literature, there are many studies examining studentcentered teaching methods in terms of academic achievement, attitude and anxiety. In this study, meta-analysis method was used to determine the size of the overall effect of student-centered teaching methods on the mathematics achievement, attitude to mathematics and anxiety. Nearly 300 articles, Master's and Doctoral theses were examined within the scope of the research. Conducted between 2005 and 2018, a total of 111 studies that were eligible for meta-analysis were included in this metaanalysis. As a result of the study, it was concluded that student-centered teaching methods were more effective on math achievement and attitude and anxiety toward mathematics than the traditional methods.

\section{Introduction}

In a constantly changing and developing world order, in order for a society to reach the level of modern civilizations, it is necessary to raise individuals who can understand and internalize the information they need and create new information by using their existing knowledge. This requirement directed the scientific world to the constructivist approach in education. According to the constructivist approach, the information learned in a meaningful way is easier to remember and more permanent than the information learned in a meaningless way (Senemoğlu, 2002). This approach, which has been taken into the center of education

\footnotetext{
*Correspondency: fatih.kezer@kocaeli.edu.tr
} 
programs in our country in recent years, aims to provide the cognitive skills (problem solving, rational, analytical, creative, hypothetical, and metacognitive thinking) that are expected to be acquired through education in the age of information and technology.

Developing problem solving ability through thinking skills takes an outstanding place among the objectives of mathematics (Baykul, 2003). Westtcott and Smith (1978) talked about the necessity of mathematics by saying "Everyone needs mathematics as a tool for doing science". For this reason, mathematics and mathematics teaching have always been considered important by all countries, and scientific and technical developments have been linked to the success in learning mathematics (Altun, 2009).

Considering the general objectives of the Secondary Mathematics Curriculum, which was renewed in 2013 to prioritize student- centered teaching methods, it has been observed that the significance of the need for individuals who value mathematics, who have advanced mathematical thinking power and who can use mathematics in modeling and problem solving has increased, and knowing mathematics provides great convenience in understanding other sciences (Bukova Güzel, 2016). With the latest changes in 2018, the content of the Secondary School Mathematics Curriculum has been simplified. In this way, meaningful learning is aimed by supporting methods that enable the student to reach the information he / she needs in daily life under the guidance of the teacher.

Beyond knowing mathematics, it is necessary to understand mathematics. When it is noticed that understanding is a different phenomenon from knowing both quantitative and qualitative wise, the questions "how did he understand that?" and "what ideas did he associate to conclude that?" gain significance rather than the mere question "does he know that?" (Van De Walle, Karp \& Bay Willams, 1997/2016). From this point of view, it would be beneficial for students to gain more permanent information by foregrounding the approaches where the process gains importance rather than the product-oriented approach in mathematics teaching. The general aim of teaching mathematics is to teach students the math knowledge and skills required in daily life, to teach them problem solving and to make them acquire a way of thinking to handle issues through the problem solving approach (Altun, 2001). In the solution of the problems, rather than the solution itself, the process (path of thinking) in that solution is among the important issues to be considered in terms of the structure of mathematics in mathematics teaching (Baykul, 2003). The learner should proceed by following the instructions of his teacher, who is a guide in the learning process, with his active participation, not without making sense of the knowledge or by memorizing, but by building up new knowledge by using prior knowledge. For this reason, student-centered teaching methods should be preferred more than the traditional methods in which the teacher or learner? is active at the center, as any community would seek for students who think rationally, take responsibility for their learning, and solve problems rather than staying passive, learning without questioning or by memorizing. Student-centered teaching methods should rather be used where preliminary information is used to build new information and the content is created in line with the needs of the student, with activities that make the student active and practitioner.

Using the right teaching methods and techniques by selecting and planning the course according to the outcomes, content, students' level of development, classroom climate, and physical facilities of the school is one of the steps leading to success, but it is not sufficient alone. Studies show that a quarter of the differences between individuals' learning come from affective characteristics, and experts have identified many components that reflect affective 
characteristics such as attitude, anxiety, self-perception, interest, and values (Baykul, 2003; Tekindal, 2015). In fact, nxiety and attitude have an important place among these affective characteristics. Yücel and Koç (2011) calculated the relationship between primary school students' mathematics attitude scores and mathematics achievement scores using the Pearson correlation coefficient and found $\mathrm{r}=0.41(\mathrm{p}=0.00)$. This result indicates that there is a moderate positive correlation between mathematics attitude and achievement.

Attitude is defined as a set of learned orientations used to react characteristically to specific stimuli (Cohen \& Swerdlik, 2013). İnceoğlu (2000), on the other hand, states that 'Attitude is a mental, emotional and behavioral reaction; a pre-disposition that the individual organizes based on their experience, motivation and knowledge against themselves or any object, social issue or event around themselves. There are 3 basic elements of attitude: cognitive, affective, and behavioral (Krech et al., 1962; Thurstone, 1928). The cognitive element of attitude includes the thoughts we have about the object of attitude (Demirtaş Madran, 2012). For example, it is the cognitive dimension of attitude to think that smoking is harmful to health due to the fatal effects of smoking. The relation of the individual's tendencies about the environment with the pleasant/unpleasant or desirable/undesirable events constitutes the affective dimension of the attitude (Tavşanc1l, 2014). The behavioral element of attitude is related with the individual's tendencies to behave towards a certain stimulus (Tavşanc1l, 2014). Morgan (1995/2011) said that the behavioral component of an attitude is "the tendency to act in accordance with conception and emotion". Thinking that smoking is harmful to health and thus keeping away from it is an example of the behavioral element of attitude. Attitude scales are created for the purpose of numerically evaluating an individual's tendencies towards a given attitude object according to certain rules (Baysal, 1981). Measurement of attitude starts in the 19th century and shows great improvement in the 20th century and meets many needs today (Özgüven, 2015). Kocayörük and Çelik (2009) stated that anxiety, apart from attitude, is one of the factors affecting learning, too.

Anxiety, which is one of the affective features, was defined by Özgüven (2015) as "unpleasant, emotional and observable reactions such as sadness, perception and tension caused by stressful situations". Anxiety and fear are two concepts often confused, but there is a considerable difference between them. While fear is a sense with a known cause; anxiety is an obscure fear that is felt without knowing what the cause is (Morgan, 2011). According to $\mathrm{O}^{\prime}$ Gorman, anxiety is a state of worry about an uncertain future. Negative thoughts and beliefs towards any object are also factors that affect anxiety. For example, many students develop negative attitude and anxiety, thinking that math is difficult, and they will fail. Yenilmez and Özbey (2006) stated in their study that there is a significant relationship between students' general achievements and their anxiety levels, and the higher the general achievement level, the lower the anxiety towards mathematics. Unless the problem of anxiety is solved, the interest and motivation of the student will gradually decrease, he/she will fail, and as a result, it will be inevitable for him/her to develop a negative attitude towards the school. For this reason, various methods should be developed to determine the cause of the anxiety related to mathematics and to decrease its level, and the level of effectiveness of these methods should be investigated.

Being successful in a subject is not merely related to the mental activities, but also to affective readiness. Individuals' showing a positive or negative attitude towards a lesson or their anxiety levels may also be affected by the form and quality of the teaching experiences they encounter (Altun, 2009). For this reason, creating teaching methods and techniques to be used by a teacher with an awareness of anxiety would provide a better motivation for the students 
and it would ensure a mutual satisfaction for both the teacher and the student.

It has become the priority of every society to create educational experiences that provide all kinds of modern educational tools and materials brought by scientific and technological processes, and that meet the needs of the learning individuals according to their capacities. In the literature, many studies that examine the level of the effect of student-centered teaching methods on academic achievement, attitude and on anxiety were found for mathematics. It was observed that different results were obtained in each of these studies, where different methods and techniques were used for different samples on similar subjects. This metaanalysis aims to determine the general effect of student-centered teaching methods used in mathematics courses on academic achievement, attitude, and anxiety. In addition, the effects of student-centered methods on achievement, attitude and anxiety were examined separately according to school levels in order to make the results more reliable with a view to attaining a more detailed interpretation. In the research, answers to the following questions were sought:

(1) What is the effect of student-centered teaching methods used in primary school mathematics courses on achievement, attitude and anxiety relating mathematics?

(2) What is the effect of student-centered teaching methods used in middle school mathematics courses on achievement, attitude and anxiety relating mathematics?

(3) What is the effect of student-centered teaching methods used in high school mathematics courses on achievement, attitude and anxiety relating mathematics?

Since this research combines the results of many independent studies examining the effect of student-centered teaching methods on mathematics achievement, attitude and anxiety, it will provide more comprehensive findings in a larger sample and give a more reliable interpretation. Also, this research is thought to give information to educators about the results of using contemporary methods and techniques instead of traditional methods in the process of organizing their educational experiences. Beyda Topan (2013) in her study entitled "The effectiveness of student-centered teaching methods on academic achievement and attitude towards the course in mathematics teaching: A meta-analysis study," investigated the effect of student-centered methods on achievement and attitude.

In this research, studies that examine the effect of student-centered method on anxiety were also combined with meta-analysis apart from the effect of it on achievement and attitude.

\section{Method}

\section{Research Model}

The research is a descriptive research since it aims to gather information about the effect of student-centered teaching methods on academic achievement, attitude, and anxiety in mathematics. Studies investigating the effect of student-centered teaching methods on mathematics achievement, attitude and anxiety were combined with meta-analysis method in this study.

\section{Meta-analysis}

Multiple opinions are put forward about the definition of meta-analysis. The meaning of the meta-analysis is stated as the collection of the analyzses or the top analysis (Borenstein, Hedges, Higgins \& Rothstein, 2009). Meta-analysis is a method that combines the synthesis of the results of previously conducted independent studies with statistical methods and gives 
more information than the included studies (Bakioğlu \& Özcan, 2016; Lipsey \& Wilson, 2000; Olkin, 1999). Meta-analysis is the systematic combination and synthesis of the results of individual studies carried out by scientists, with the purpose of interpreting in the best possible manner of those results obtained from a large number of studies on a similar subject (Card, 2011).

Systematic construction of new studies on the basis of previous studies is important in terms of contributing to the advancement of scientific knowledge. The findings of a study can be repeated with meta-analysis, which is related to the principle of repeating scientific knowledge with experiments and observations (Card, 2011). In addition, by calculating the effect size of each study, the opportunity to make comparisons between the studies can be obtained by meta-analysis (Dinçer, 2014).

\section{Process Steps in Meta-Analysis} 2016):

The directive regarding the meta-analysis steps is given below (Bakioğlu \& Özcan,

- To define the subject of the research and the research problem,

- To formulate the hypotheses to be tested in the research,

- To determine the inclusion criteria of the studies to be included in the research,

- To create a database for the analysis of the research,

- To determine common measures for research analysis,

- To combine the results of research analysis,

- To put the results of research analysis into a report.

\section{Effect Size}

Cohen defined the effect size as the degree of presence of any phenomenon in a cluster/group or population (Çelebi Yıldı, 2002). The effect size, also known as the effect width, is used in a study to give information about the extent to which the independent variable affects the dependent variable positively and negatively (Dinçer, 2014). The effect size is a quantitative value that gives information about the magnitude of the difference the two groups have (Coe, 2017). In a problem that investigates whether a method is effective or not, it answers the question "How much does it work?" rather than "Does it work?". Interpretation of the effect size of the studies is made according to the classification made by Cohen and his friends. According to this,

- $-0.15 \leq$ effect size coefficient $<0.15$ insignificant level

- $0.15 \leq$ effect size coefficient $<0.40 \quad$ small level

- $0.40 \leq$ effect size coefficient $<0.75$ medium level

- $0.75 \leq$ effect size coefficient $<1.10 \quad$ large level

- $1.10 \leq$ effect size coefficient $<1.45$ very large level

- $1.45 \leq$ effect size coefficient $<\infty \quad$ excellent

After calculating the effect size of each of the studies included in the meta-analysis, a general effect size coefficient is obtained in line with the appropriate model chosen. 


\section{Heterogeneity Test}

The heterogeneity test is effective in determining the model that should be chosen in calculating the overall effect. If the significance value obtained from the Q statistics is less than 0.05, it indicates that the studies included in the meta-analysis are heterogeneous. If the $\mathrm{Q}$ value obtained from the test is greater than the value corresponding to the degree of freedom in the table, the same interpretation is made. Since, in this case, the studies are not considered to be similar in order to calculate the overall effect, analysis is made on the basis of the random effects model. If the significance value is greater than 0.05 , the fixed effects model is preferred, wherein the variance of the studies is assumed to be equal to zero (Dinçer, 2014).

\section{Data}

In the process of collecting the studies to be included in the meta-analysis, publishedunpublished articles, master's theses, doctoral theses, and academic papers were investigated. In accessing these studies, the key words such as 'Mathematics achievement', 'mathematics attitude', 'mathematics anxiety', 'cooperative learning method', 'collaborative learning', 'project based learning', 'problem solving method', 'student centered methods' were used through browsing the pages of the ' Higher Education Council National Thesis Center, National Academic Network and Information Center (ULAKBİM) and Google Scholar engine. To decide which studies will be analyzed as a result of the screening; variables such as year of research, research design, teaching level, statistics used in effect size calculation, mathematics achievement, attitude and anxiety have been chosen as the criteria of inclusion. Since student-centered teaching methods were put into the practice in teaching programs as of 2005 , the results of the research conducted since 2005 were included in meta-analysis. As a result, of about more than 300 studies, a total of 111 studies conducted between 2005 and 2018 that met the criteria were included in this study. 54 studies examining the effect of studentcentered teaching methods on mathematics achievement, 42 studies on mathematics attitude and 15 studies on mathematics anxiety were reached. Since a sufficient number of studies could not be reached for university and for the pre-school level, studies consisting of university and pre-school students were not included in the meta-analysis herein.

\section{Descriptive Data on Studies Investigating the Effect of Student-Centered Methods Used in Mathematics Teaching on Academic Achievement}

Frequency and percentage distributions of the 54 studies examining the effect of student-centered methods on academic achievement in mathematics teaching since 2005 are given in Tables 1, 2 and 3, respectively, according to the year, publication type and level of education.

Table 1. Frequency and Percentage Distributions by Years Regarding Studies Examining the Effect of Student Centered Methods Used in Mathematics Teaching on Academic Achievement.

\begin{tabular}{lrrllr}
\hline Year & f & \% & Year & f & \% \\
\hline 2005 & 4 & 7,3 & 2012 & 3 & 5,6 \\
2006 & 1 & 1,9 & 2013 & 2 & 3,7 \\
2007 & 11 & 20,4 & 2014 & 3 & 5,6 \\
2008 & 3 & 5,6 & 2015 & 3 & 5,6 \\
2009 & 3 & 5,6 & 2016 & 4 & 7,3 \\
2010 & 2 & 3,7 & 2017 & 4 & 7,3 \\
2011 & 8 & 14,8 & 2018 & 3 & 5,6 \\
& & & Total & 54 & 100,0 \\
\hline
\end{tabular}


According to Table 1, the year in which the highest numbers of studies were carried out was 2007 by $20.4 \%$ while 2006 is the year in which the effects of student-centered methods on mathematics achievement were examined the least, by $1.9 \%$.

Table 2. Frequency and Percentage Distributions According to Publication Type Regarding Studies Examining the Effect of Student Centered Methods Used in Mathematics Teaching on Academic Achievement

\begin{tabular}{lrr}
\hline Publication Type & f & \% \\
\hline Article & 4 & 7,4 \\
Masters Thesis & 46 & 85,2 \\
Doctoral Thesis & 4 & 7,4 \\
TOTAL & 54 & 100,0 \\
\hline
\end{tabular}

According to Table 2, among the studies included in the research, the highest number of studies are master's theses by $85.2 \%$, and it is seen that the number of articles and doctoral theses are equal, having a share of $7.4 \%$.

Table 3. Frequency and Percentage Distributions According to Teaching Levels Regarding the Studies that Examine the Effect of Student Centered Methods Used in Mathematics Teaching on Academic Achievement

\begin{tabular}{lrr}
\hline School Levels & f & \% \\
\hline Primary School & 12 & 22,2 \\
Middle School & 34 & 63,0 \\
High School & 8 & 14,8 \\
TOTAL & 54 & 100,0 \\
\hline
\end{tabular}

Studies examining academic achievement are at the highest level for middle school by $63 \%$ while they are at the lowest for high school level, by $14.8 \%$.

\section{Descriptive Data on Studies Investigating the Effects of Student-Centered Methods} Used in Mathematics Teaching on Mathematics Attitude

Frequency and percentage distributions according to the year, publication type and level of education regarding 42 studies examining the effect of student-centered methods used in mathematics teaching on mathematics attitude are given in Tables 4, 5 and 6, respectively.

Table 4. Frequency and Percentage Distributions by Years Regarding the Studies Examining the Effect of Student-Centered Methods Used in Mathematics Teaching on the Mathematics Attitude

\begin{tabular}{lrr}
\hline Year & f & \% \\
\hline 2005 & 4 & 9,6 \\
2006 & 2 & 4,8 \\
2007 & 8 & 19,0 \\
2008 & 5 & 11,9 \\
2009 & 3 & 7,1 \\
2010 & 3 & 7,1 \\
2011 & 5 & 11,9 \\
2012 & 2 & 4,8 \\
2013 & 1 & 2,4 \\
2014 & 3 & 7,1 \\
2015 & 1 & 2,4 \\
2016 & 3 & 7,1 \\
2017 & 2 & 4,8 \\
Total & 42 & 100,0 \\
\hline
\end{tabular}


When the studies examining the effects of student-centered methods on mathematics attitude are analyzed, the year in which the highest number of studies was conducted is seen to be 2007 by $19 \% .2008$ and 2011 are the years with a high number of work, by 11.9\%. 2013 and 2015 , with $2.4 \%$, are seen to be the years in which the effects of student-centered methods on mathematics attitude were examined the least.

Table 5. Frequency and Percentage Distributions According to the Type of Publication Regarding the Studies Examining the Effect of Student-Centered Methods Used in Mathematics Teaching on Mathematics Attitude

\begin{tabular}{lrr}
\hline Publication Type & f & \% \\
\hline Article & 3 & 7,1 \\
Master's Thesis & 33 & 78,6 \\
Doctoral Thesis & 6 & 14,3 \\
TOTAL & 42 & 100,0 \\
\hline
\end{tabular}

According to Table 5, the highest number of studies conducted is the Master's thesis studies by $78.6 \%$, and it is seen that articles are the least by $7.1 \%$.

Table 6. Frequency and Percentage Distributions According to the Levels of Education Regarding the Studies Examining the Effect of Student-Centered Methods Used in Mathematics Teaching on Mathematics Attitude

\begin{tabular}{lrr}
\hline School Levels & f & \% \\
\hline Primary School & 9 & 21,4 \\
Middle School & 28 & 66,7 \\
High School & 5 & 11,9 \\
TOTAL & 42 & 100,0 \\
\hline
\end{tabular}

Maximum number of studies examining the mathematics attitude according to level of education is for middle school by $66.7 \%$ while the minimum figure for the same is for high school, by $11.9 \%$. It is seen that $21.4 \%$ of the studies are for primary school.

Descriptive Data on Studies Investigating the Effects of Student-Centered Methods Used in Mathematics Teaching on Mathematics Anxiety

Frequency and percentage distributions according to the year, type of publication, and level of education regarding 15 studies investigating the effect level of student-centered methods used in mathematics teaching on mathematics anxiety since 2005 are given in Tables 7,8 and 9 , respectively.

Table 7. Frequency and Percentage Distributions by Years Regarding Studies Examining the Effects of Student-Centered Methods Used in Mathematics Teaching on Mathematics Anxiety

\begin{tabular}{lrr}
\hline Year & f & \% \\
\hline 2007 & 3 & 20,0 \\
2008 & 4 & 26,8 \\
2009 & 1 & 6,7 \\
2011 & 2 & 13,3 \\
2014 & 1 & 6,7 \\
2015 & 1 & 6,7 \\
2016 & 2 & 13,3 \\
2018 & 1 & 6,7 \\
Total & 15 & 100,0 \\
\hline
\end{tabular}


When Table 7 is analyzed, the year in which the highest number of studies were conducted was 2008 by 26.8\%; while the years 2009, 2014, 2015, and 2018 are seen as the years when the effects of student-centered methods on mathematics anxiety were least studied by $6.7 \%$.

Table 8. Frequency and Percentage Distributions According to the Type of Publication Regarding the Studies Examining the Effects of Student-Centered Methods Used in Mathematics Teaching on Mathematics Anxiety

\begin{tabular}{lrc}
\hline Publication Type & f & \% \\
\hline Article & 0 & 0,0 \\
Master's Thesis & 13 & 86,7 \\
Doctoral Thesis & 2 & 13,3 \\
TOTAL & 15 & 100,0 \\
\hline
\end{tabular}

According to Table 8, among the studies included in the research, the Master's theses constitute the highest number of work on mathematics anxiety by $86.7 \%$, followed by doctoral theses by $13.3 \%$. No studies have been encountered in the category of articles.

Table 9. Frequency and Percentage Distributions According to Teaching Levels Regarding the Studies Examining the Effects of Student-Centered Methods Used in Mathematics Teaching on Mathematics Anxiety

\begin{tabular}{lrc}
\hline School Levels & f & \% \\
\hline Primary School & 2 & 13,3 \\
Middle School & 13 & 86,7 \\
High School & 0 & 0,0 \\
TOTAL & 15 & 100 \\
\hline
\end{tabular}

As seen in Table 9, in terms of educational levels, middle school constitutes the highest percentage by $86.7 \%$, followed by $13.3 \%$ on primary school. No studies have been accessed for the high school level.

\section{Data Analysis}

In the analysis of the data, meta-analysis was performed by calculating the effect size through the difference of standardized arithmetic averages. The effect size of each study was calculated individually by using the arithmetic means of the experimental and control groups, the standard deviations and sample numbers. The standardized mean difference effect size is found by dividing the difference between the arithmetic means of the groups by the standard deviation of all values (Bakioğlu \& Özcan, 2016).

Statistical significance level was taken as 0.05 in the study. Through heterogeneity test, in other words, as a result of $\mathrm{Q}$ statistics, it is concluded that individual studies are heterogeneous if $\mathrm{p}$ value is less than 0.05 . If the studies are heterogeneous, random effects model is used, if homogeneous, fixed effects model is used. In this research, the CMA (Comprehensive Meta-Analysis) software, which has a wide range of features, was used to calculate the effect size and overall effect size of the studies included in the meta-analysis.

\section{Findings}

The findings obtained as a result of the meta-analysis of 111 studies included in the study were reported separately in view of achievement, attitude and anxiety. 


\section{The Effect of Student-Centered Methods Used in Mathematics Teaching on Academic Achievement}

It was observed that the effect sizes of the studies examining the effect of studentcentered methods on mathematics achievement ranged from -0.274 to 2.027. The distributions of the studies in relation to direction of the effect size are given in Table 10.

Table 10. Frequency and Percentage Distributions Regarding the Direction of the Effect Size of the Studies Examining the Effect of Student Centered Methods on Mathematics Achievement

\begin{tabular}{lrr}
\hline Direction & f & \% \\
\hline Pozitive & 53 & 98.1 \\
Zero & 0 & 0.0 \\
Negative & 1 & 1.9 \\
Total & 54 & 100.0 \\
\hline
\end{tabular}

As can be seen in Table 10, $53(98.1 \%)$ of 54 studies were positive, and 1 (1.9\%) had negative effect size. The effect size coefficients of the studies are given in Table 11 as insignificant, small, medium, large, very large and excellent level according to the classification created for Cohen's d.

Table 11. Frequency and Percentage Distributions, According to Cohen's Effect Size Classification, of the Effect Size of Studies Examining the Effect of Student Centered Methods on Mathematics Achievement

\begin{tabular}{lrr}
\hline Effect Size & f & \% \\
\hline Insignificant & 2 & 3.7 \\
Small & 6 & 11.1 \\
Medium & 21 & 38.9 \\
Large & 12 & 22.2 \\
Very Large & 5 & 9.3 \\
Excellent & 8 & 14.8 \\
Total & 54 & 100.0 \\
\hline
\end{tabular}

According to Table 11, the effect sizes of the studies are at medium level for 21 studies (38.9\%), and at insignificant level for 2 studies (3.7\%). According to the fixed and random effects models of the studies, the overall effect size, standard error, variance, lower and upper limit value in $95 \%$ confidence interval, $\mathrm{z}$ and $\mathrm{p}$ values and the $\mathrm{Q}$ value obtained from the heterogeneity test are given in Table 12 below.

Table 12. Comparison of the Effect Size of Student-Centered Methods Used in Mathematics Teaching According to the Fixed and Random Effects Models on Academic Achievement

\begin{tabular}{llllllllll}
\hline Model & N & ES & $\mathbf{Q}$ & $\begin{array}{l}\text { Std. } \\
\text { Error }\end{array}$ & Variance & $\begin{array}{l}\text { Lower } \\
\text { Limit }\end{array}$ & $\begin{array}{l}\text { Upper } \\
\text { Limit }\end{array}$ & z & p \\
\hline Fixed Effects Model & 54 & 0.779 & 153.601 & 0.036 & 0.001 & 0.708 & 0.850 & 21.571 & 0.000 \\
$\begin{array}{l}\text { Random Effects } \\
\text { Model }\end{array}$ & 54 & 0.811 & 153.601 & 0.062 & 0.004 & 0.690 & 0.933 & 13.075 & 0.000 \\
\hline
\end{tabular}

As a result of the heterogeneity test of the studies included in the research, the $Q$ value was found to be 153.601. Since the $Q$ value (153.601) obtained from the $\chi^{2}$ table compared to the critical value $($ Qcritical $=67.50)$ at $95 \%$ significance level is greater than the critical value, 
the effect sizes of the studies included in the study were identified to have a heterogeneous distribution $(\mathrm{p}=0.00<0.05)$. The overall effect size was found to be 0.811 according to the random effects model, considering the heterogeneous distribution (Table 12). In the 95\% confidence interval, the lower limit is 0.690 and the upper limit is 0.933 , and according to Cohen's classification, the overall effect size value is in the category of large range. The $\mathrm{z}$ value indicating the level of statistical significance was found to be 13,075 , and the overall effect size was found to be significant along with the $p=0,000$ value $(p<0.05)$. The result is in favor of student-centered teaching methods on mathematics achievement. It can be said that student-centered teaching methods are more effective on mathematics achievement than the teaching methods in which the teacher is at the center.

\section{The Effect of Student-Centered Methods Used in Mathematics Teaching on Academic Achievement According to Teaching Levels}

While investigating the effect of student-centered methods on academic achievement, the effect sizes of the studies were examined according to three different education levels and summarized in Table 13.

Table 13. Lowest and Highest Values of Effect Sizes (ES) According to the Levels of Teaching

\begin{tabular}{lcll}
\hline School Levels & N & Lowest ES & Highest ES \\
\hline Primary School & 12 & 0.249 & 1.861 \\
Middle School & 34 & 0.208 & 2.027 \\
High School & 7 & -0.274 & 1.828 \\
\hline
\end{tabular}

When the distribution of studies related to the direction of effect size is examined, it is observed that all studies in primary school and middle school $(100 \%)$ and $87.5 \%(f=7)$ of eight studies in high school are positive. It can be interpreted that almost all of the effect sizes are positive, and student-centered methods in teaching mathematics are highly effective on academic achievement. The distribution of effect size coefficients of the studies is given in Table 14.

Table 14. Frequency and Percentage Distributions of the Effect Size of Studies Examining the Effect of Student Centered Methods on Mathematics Achievement in Mathematics Education According to Cohen's Effect Size Classification

\begin{tabular}{lrrrrrr}
\hline \multirow{2}{*}{ Effect Size Level } & \multicolumn{2}{c}{ Primary School } & \multicolumn{2}{c}{ Middle School } & \multicolumn{2}{c}{ High School } \\
\cline { 2 - 7 } & f & \% & f & \% & f & \% \\
\hline Insignificant & 0 & 0.0 & 0 & 0.0 & 2 & 25.0 \\
Small & 3 & 25.0 & 3 & 8.8 & 0 & 0.0 \\
Medium & 2 & 16.7 & 17 & 50.0 & 2 & 25.0 \\
Large & 5 & 41.6 & 5 & 14.7 & 2 & 25.0 \\
Very Large & 0 & 0.0 & 4 & 11.8 & 1 & 12.5 \\
Excellent & 2 & 16.7 & 5 & 14.7 & 1 & 12.5 \\
TOTAL & 12 & 100.0 & 34 & 100.0 & 8 & 100.0 \\
\hline
\end{tabular}

As seen in Table 14, the effect sizes of the studies conducted in primary school are seen to be at large level with maximum 5 studies (41.6\%) while the effect sizes of the studies carried out in middle school are at the medium level with a maximum of 17 studies $(50 \%)$. It is seen that the effect sizes of the studies conducted in high school are very large and excellent for at least one study for each category. No studies with small effect size have been encountered with 
respect to Cohen's classification for the high school level.

$\mathrm{Q}$ values and $\mathrm{p}$ significance values were examined for the heterogeneity test. The $\mathrm{Q}$ value of the studies in primary school was calculated to be 30.807. Since they are greater than the table value 19.675, the effect sizes were observed to be heterogeneous $(\mathrm{p}<0.05)$. As a result of the heterogeneity test in middle school, Q value was found to be 87.876. Since the critical Q value is greater than 43,773 with 33 degrees of freedom, the effect sizes were seen to be heterogeneous ( $\mathrm{p}<0.05$ ). The $\mathrm{Q}$ value of eight studies in high school was found to be 32,575. Again, since the critical Q value at $95 \%$ confidence level is greater than 14.067, the effect sizes are considered to have a heterogeneous distribution ( $\mathrm{p}<0.05)$. The overall effect size was interpreted according to the random effects model in line with heterogeneous distributions in all three levels. Comparative results of the studies according to the fixed and random effects models are given in Table 15.

Table 15. Comparison of the Effect Size of Student-Centered Methods Used on Academic Achievement According to the Fixed and Random Effects Model

\begin{tabular}{llllllllll}
\hline Model & $\mathbf{N}$ & $\mathbf{E S}$ & $\mathbf{Q}$ & $\begin{array}{l}\text { Std. } \\
\text { Error }\end{array}$ & Variance & $\begin{array}{l}\text { Lower } \\
\text { Limit }\end{array}$ & $\begin{array}{l}\text { Upper } \\
\text { Limit }\end{array}$ & $\mathbf{z}$ & $\mathbf{p}$ \\
\hline $\begin{array}{l}\text { Primary School } \\
\text { Fixed Effects }\end{array}$ & 12 & 0.826 & 30.807 & 0.078 & 0.006 & 0.674 & 0.978 & 10.647 & 0.000 \\
$\begin{array}{l}\text { Model } \\
\begin{array}{l}\text { Random } \\
\text { Effects Model }\end{array}\end{array}$ & 12 & 0.824 & 30.807 & 0.131 & 0.017 & 0.568 & 1.081 & 6.306 & 0.000 \\
\hline $\begin{array}{l}\text { Middle School } \\
\text { Fixed Effects }\end{array}$ & 34 & 0.792 & 87.876 & 0.045 & 0.002 & 0.704 & 0.881 & 17.552 & 0.000 \\
$\begin{array}{l}\text { Model } \\
\begin{array}{l}\text { Random } \\
\text { Effects Model }\end{array}\end{array}$ & 34 & 0.831 & 87.876 & 0.074 & 0.006 & 0.685 & 0.976 & 11.170 & 0.000 \\
\hline $\begin{array}{l}\text { High School } \\
\text { Fixed Effects }\end{array}$ & 8 & 0.648 & 32.575 & 0.095 & 0.009 & 0.461 & 0.835 & 5.797 & 0.000 \\
$\begin{array}{l}\text { Model } \\
\begin{array}{l}\text { Random } \\
\text { Effects Model }\end{array}\end{array}$ & 8 & 0.708 & 32.575 & 0.210 & 0.044 & 0.296 & 1.120 & 3.370 & 0.001 \\
\hline
\end{tabular}

As can be seen in Table 15, the overall effect size of the studies conducted in primary school was found to be 0.824 according to the random effects model. In the $95 \%$ confidence interval, the lower limit is 0.568 and the upper limit is 1.081, and according to Cohen's classification, the overall effect size value has a large impact. Denoting the statistical significance level, the $\mathrm{z}$ statistic/value was found to be 6.306 , and the overall effect size was found to be significant along with the $\mathrm{p}$ value $0,000(\mathrm{p}<0.05)$. The overall effect size of the studies conducted in middle school was found to be $0.831(\mathrm{z}=11.170, \mathrm{p}<0.05)$. According to Cohen's classification, the effect size corresponds to large effect category at this level, too. The overall effect size in high school was found to be $0.708(\mathrm{z}=3.370, \mathrm{p}<0.05)$. In the $95 \%$ confidence interval, the lower limit was 0.296 and the upper limit was 1.120, and the overall effect size value is medium. It can be said that student-centered methods are highly effective on mathematics achievement in the three levels of education in terms of both fixed and random effects models.

\section{The Effect of Student-Centered Methods Used in Mathematics Teaching on Mathematics Attitude}

In 42 studies in which the effect of student-centered methods on mathematics attitude was examined, the effect sizes varied between $-0,268$ and 1,239 values. When the effect sizes 
were analyzed, the effect size of $37(88.1 \%)$ studies was found positive, of $1(2.4 \%)$ study was zero, and of $4(9.5 \%)$ studies was negative. It can be said that student-centered methods in mathematics teaching have a positive effect on mathematics attitude, since the effect sizes of studies are positive by $88.1 \%$. The effect size coefficients of the studies are given in Table 16 .

Table 16. Frequency and Percentage Distributions According to Cohen's Effect Size Classification of the Effect Size of Studies Examining the Effect of Student Centered Methods on Mathematics Attitude

\begin{tabular}{lrc}
\hline Effect Size & f & \% \\
\hline Insignificant & 8 & 19.0 \\
Small & 8 & 19.0 \\
Medium & 12 & 28.6 \\
Large & 10 & 23.8 \\
Very Large & 4 & 9.6 \\
Excellent & 0 & 0.0 \\
Total & 41 & 100.0 \\
\hline
\end{tabular}

According to the effect size classification, the effect sizes of the studies are at medium level with 12 studies at the highest $(28.6 \%)$ and at very large level with 4 studies $(9.6 \%)$ at the very least. No studies covered by the meta-analysis were found to have an excellent effect size. Comparative results of the studies according to the fixed and random effects models are given in Table 17.

Table 17. Comparison of the Effect Size of Student-Centered Methods Used in Mathematics Teaching According to the Fixed and Random Effects Models on Mathematics Attitude

\begin{tabular}{llllllllll}
\hline Model & N & ES & Q & $\begin{array}{l}\text { Std. } \\
\text { Error }\end{array}$ & Variance & $\begin{array}{l}\text { Lower } \\
\text { Limit }\end{array}$ & $\begin{array}{l}\text { Upper } \\
\text { Limit }\end{array}$ & z & $\mathbf{p}$ \\
\hline Fixed Effects Model & 42 & 0.512 & 93.960 & 0.040 & 0.002 & 0.433 & 0.591 & 12.694 & 0.000 \\
Random Effects Model & 41 & 0.530 & 93.960 & 0.062 & 0.004 & 0.408 & 0.651 & 8.543 & 0.000 \\
\hline
\end{tabular}

As a result of the homogeneity test of the studies included in the research, the Q value was found to be 93.960 ( $p<0.05)$. Since this value was greater than the critical $Q$ value $(55,758)$ with 41 degrees of freedom, it was determined that the effect sizes of the studies showed a heterogeneous distribution. As seen in Table 17, the overall effect size of the student-centered methods according to the random effects model on mathematics attitude was found to be $0.530(\mathrm{z}=8.543, \mathrm{p}<0.05)$. In the $95 \%$ confidence interval, the lower limit is 0.408 and the upper limit is 0.651 and the overall effect size value corresponds to the medium effect category. Thus, the result is in favor of student-centered teaching methods on mathematics attitude.

\section{The Effect of Student-Centered Methods Used in Mathematics Education on}

\section{Mathematics Attitude According to Teaching Levels}

The effect of student-centered methods on a mathematics attitude in three different levels as primary school, middle school and high school were investigated and the effect sizes of the studies were examined, and they are summarized in Table 18. 
Table 18. Lowest and Highest Values of Effect Sizes (ES) According to Levels of Teaching

\begin{tabular}{lcll}
\hline School Levels & N & Lowest ES & Highest ES \\
\hline Primary School & 9 & 0.000 & 1.198 \\
Middle School & 28 & -0.268 & 1.239 \\
High School & 5 & 0.127 & 1.063 \\
\hline
\end{tabular}

When the distribution of the studies included in the study regarding the effect size is analyzed, the effect sizes of all the studies in primary school and high school levels are seen to be positive while $25(89.3 \%)$ of 28 studies in middle school have positive effect and 3 studies $(10.7 \%)$ have negative effect size. The fact that the effect sizes are largely positive can be interpreted as a clue in showing the positive effect of student-centered methods on attitude towards mathematics. The effect size coefficients of the studies are given in Table 19.

Table 19. Frequency and Percentage Distributions, According to Cohen's Effect Size Classification, of the Effect Sizes of Studies Examining the Effect of Student-Centered Methods on Mathematics Attitude

\begin{tabular}{lcrrrrr}
\hline \multirow{2}{*}{ Effect Size Level } & \multicolumn{2}{c}{ Primary School } & \multicolumn{2}{c}{ Middle School } & \multicolumn{2}{c}{ High School } \\
\cline { 2 - 7 } & f & \% & f & \% & f & \% \\
\hline Insignificant & 2 & 22.2 & 5 & 17.9 & 1 & 20.0 \\
Small & 2 & 22.2 & 6 & 21.4 & 0 & 0.0 \\
Medium & 2 & 22.2 & 9 & 32.1 & 1 & 20.0 \\
Large & 2 & 22.2 & 5 & 17.9 & 3 & 60.0 \\
Very Large & 1 & 11.1 & 3 & 10.7 & 0 & 0.0 \\
Excellent & 0 & 0.0 & 0 & 0.0 & 0 & 0.0 \\
TOTAL & 9 & 100.0 & 28 & 100.0 & 5 & 100.0 \\
\hline
\end{tabular}

When the effect sizes were analyzed, it is observed that the effect sizes of the studies in primary school are distributed equally at small, medium, and large levels (22.2\%). While it is eye catching that, of the studies in middle school, nine have a medium effect size by $32.1 \%$, three studies in high school have a large impact size. According to Cohen's classification, there was no study with excellent level in all of the three education levels.

The Q value of the studies in primary school was found to be 17.421. Since they are greater than the table value, ie. 15.507, the effect sizes were observed to be heterogeneous ( $p<0.05)$. As a result of the heterogeneity test for middle school, Q value was found to be 64.687. Since the critical Q value is greater than 40.113, it has been found out that the effect sizes show heterogeneous distribution ( $\mathrm{p}<0.05$ ). The $\mathrm{Q}$ value of five studies for high school was found to be 6.495. Since the critical Q value at $95 \%$ confidence level was 9.488, the calculated Q value was lower than this value ( $>>005)$. It was found out that the effect sizes of the studies in high school showed a homogeneous distribution. Thus, while the results are reported according to random effects model for primary school and middle school, the reports are given according to fixed effects model for high school. Comparative results of the studies according to the fixed and random effects models are given in Table 20. 
Table 20. Comparison of the Effect Sizes of Student-Centered Methods Used in Mathematics Teaching According to the Fixed and Random Effects Model on Mathematics Attitude

\begin{tabular}{|c|c|c|c|c|c|c|c|c|c|}
\hline Model & $\mathbf{N}$ & ES & $\mathbf{Q}$ & $\begin{array}{l}\text { Std. } \\
\text { Error }\end{array}$ & $\begin{array}{l}\text { Varianc } \\
\text { e }\end{array}$ & $\begin{array}{l}\text { Lower } \\
\text { Limit }\end{array}$ & $\begin{array}{l}\text { Upper } \\
\text { Limit }\end{array}$ & $\mathbf{z}$ & $\mathbf{p}$ \\
\hline \multicolumn{10}{|l|}{ Primary School } \\
\hline Fixed Effects Model & 9 & 0.495 & 17.421 & 0.082 & 0.007 & 0.334 & 0.656 & 6.020 & 0.000 \\
\hline $\begin{array}{l}\text { Random Effects } \\
\text { Model }\end{array}$ & 9 & 0.532 & 17.421 & 0.128 & 0.016 & 0.282 & 0.783 & 4.162 & 0.000 \\
\hline \multicolumn{10}{|l|}{ Middle School } \\
\hline Fixed Effects Model & 28 & 0.509 & 64.687 & 0.050 & 0.002 & 0.412 & 0.606 & 10.283 & 0.000 \\
\hline $\begin{array}{l}\text { Random Effects } \\
\text { Model }\end{array}$ & 28 & 0.515 & 64.687 & 0.077 & 0.006 & 0.363 & 0.666 & 6.670 & 0.000 \\
\hline \multicolumn{10}{|l|}{ High School } \\
\hline Fixed Effects Model & 5 & 0.650 & 6.495 & 0.131 & 0.017 & 0.393 & 0.908 & 4.951 & 0.000 \\
\hline
\end{tabular}

According to the random effects model, the overall effect size was found to be $0.532(\mathrm{z}=$ $4.162, \mathrm{p}<0.05)$ for the studies conducted in primary school. As can be seen in Table 6 , the lower limit is 0.282 and the upper limit is 0.793 within the $95 \%$ confidence interval, and according to Cohen's classification, the overall effect size value corresponds to medium category. As for middle school, the overall effect size, through the same model, was found to be $0.515(\mathrm{z}=6.670, \mathrm{p}<0.05)$. In the $95 \%$ confidence interval, the lower limit was 0.363 and the upper limit was 0.666. At this level, too, the overall effect size corresponds to medium category. The general effect size of the student-centered methods used in the high school level, in which the fixed effects model was taken into consideration, was found to be $0.650 \mathrm{z}$ $=4.951, \mathrm{p}<0.05)$. In the $95 \%$ confidence interval, the lower limit is 0.393 and the upper limit is 0.908. According to Cohen's classification, the overall effect size value corresponds to medium category also at this level of education. Stemming from the effect sizes calculated in both the fixed and the random effects models, it can be concluded that the student-centered methods have a positive effect on the student attitudes towards mathematics.

\section{The Effect of Student-Centered Methods Used in Mathematics Teaching on Mathematics Anxiety}

When effect sizes of the 15 studies included in the study were individually examined, it was observed that their effect sizes ranged from $-0,786$ to 1,334 . The distributions of the studies in view of the direction of the effect size are given in Table 21.

Table 21. Frequency and Percentage Distributions Regarding the Direction of the Effect Sizes of the Studies Examining the Effects of Student-Centered Methods on Mathematics Anxiety

\begin{tabular}{lrr}
\hline Direction & f & \% \\
\hline Pozitive & 13 & 86.7 \\
Zero & 0 & 0.0 \\
Negative & 2 & 13.3 \\
TOPLAM & 15 & 100.0 \\
\hline
\end{tabular}

As seen in Table 21, it is seen that the effect sizes of the studies $(86.7 \%)$ are positive except for two studies. The effect size coefficients of the studies are given in Table 22 . 
Table 22. Frequency and Percentage Distributions, According to Cohen's Effect Size Classification, of the Effect Size of Studies Examining the Effect of Student Centered Methods on Mathematics Anxiety.

\begin{tabular}{lrr}
\hline Effect Size & f & \% \\
\hline Insignificant & 2 & 13.3 \\
Small & 2 & 13.3 \\
Medium & 6 & 40.0 \\
Large & 4 & 26.7 \\
Very Large & 1 & 6.7 \\
Excellent & 0 & 0.0 \\
TOTAL & 15 & 100.0 \\
\hline
\end{tabular}

It is seen that the effect sizes of the studies included in the study are at medium level with 6 studies $(40.0 \%)$ at the highest and at very large level with 1 study $(6.7 \%)$ at the lowest. No study was found to have excellent level according to Cohen's effect size classification, concerning the effect of student-centered teaching methods on mathematics anxiety. Comparative results of the studies according to the fixed and random effects models are given in Table 23.

Table 23. Comparison of Effect Size of Student-Centered Methods Used in Mathematics Teaching According to the Fixed and Random Effects Models on Mathematics Anxiety

\begin{tabular}{llllllllll}
\hline Model & N & ES & Q & $\begin{array}{l}\text { Std. } \\
\text { Error }\end{array}$ & Variance & $\begin{array}{l}\text { Lower } \\
\text { Limit }\end{array}$ & $\begin{array}{l}\text { Upper } \\
\text { Limit }\end{array}$ & z & $\mathbf{p}$ \\
\hline Fixed Effects Model & 15 & 0.455 & 48.122 & 0.065 & 0.004 & 0.328 & 0.582 & 7.021 & 0.000 \\
Random Effects Model & 1 & 0.463 & 48.122 & 0.121 & 0.015 & 0.226 & 0.700 & 3.831 & 0.000 \\
& 5 & & & & & & & & \\
\hline
\end{tabular}

As a result of the homogeneity test of the studies, the $\mathrm{Q}$ value was found to be 48.122 ( $\mathrm{p}$ $<0.05)$. The effect size distribution was seen to be heterogeneous as it is greater than the critical $Q$ value $(23,685)$. As seen in Table 14, the general effect size of the student-centered methods used according to the random effects model on mathematics anxiety was calculated as $0.463(\mathrm{z}=3.831, \mathrm{p}<0.05)$. Within the confidence interval, the lower limit for the effect size is 0.226 and the upper limit is 0.700 . The calculated effect size value corresponds to the medium effect size level. As a result of the analysis, it was concluded that the findings are in favor of student-centered teaching methods on mathematics anxiety. Compared to the teaching methods in which the teacher is in the center, it is seen that student-centered teaching methods have an effect that reduces mathematics anxiety.

\section{Effect of Student-Centered Methods Used in Mathematics Teaching on Mathematics Anxiety According to Teaching Levels}

Since no studies were found on anxiety for high school education in the literature review, the examinations according to the level of education were carried out for primary and middle school education. Since bias analysis can be done when there are more than two studies, bias analysis for primary school could not be performed. Two studies in middle school were observed to be biased and thus they were excluded from the analysis. The effect size ranges of the studies are given in Table 24. 
Table 24. Lowest and Highest Values of Effect Sizes (ES) by Teaching Levels

\begin{tabular}{lcll}
\hline School Levels & N & Lowest ES & Highest ES \\
\hline Primary School & 2 & -0.786 & 0.284 \\
Middle School & 11 & 0.159 & 0.826 \\
\hline
\end{tabular}

One of the two studies at primary school has an effect size of -0.786 while the other has 0.284. According to Cohen's effect size classification, one study was in the insignificant category while the other study was in the small size effect category. Im light of those two studies, it can be said that the effect of student-centered methods on math anxiety levels is small. As for middle school, the effect size levels were found to be at medium level with six studies $(54.5 \%)$ at the highest. While there were four (36.4\%) studies with a large effect size, there was only one study $(9.1 \%)$ with a small effect size.

As a result of the heterogeneity test, the $\mathrm{Q}$ value of the two studies in primary school was found to be 8.175 ( $p<0.05)$. Since the $Q$ value is greater than 3.841 , which is the critical value, the distribution of the effect sizes of the studies is considered heterogeneous. The $\mathrm{Q}$ value of 11 studies for middle school was found to be $6.183(\mathrm{p}<0.05)$. As the critical value is 18.307 with $95 \%$ significance level and 10 degrees of freedom, the effect size distribution was considered to be homogeneous. The overall effect size of the studies was calculated according to the fixed effects model. Comparative results of the studies according to the fixed and random effects model are given in Table 25.

Table 25. Comparison of the Effect Size of Student-Centered Methods Used in Mathematics Teaching According to the Fixed and Random Effects Models on Mathematics Anxiety

\begin{tabular}{|c|c|c|c|c|c|c|c|c|c|}
\hline Model & $\mathbf{N}$ & ES & $\mathbf{Q}$ & $\begin{array}{l}\text { Std. } \\
\text { Error }\end{array}$ & $\begin{array}{l}\text { Varianc } \\
\text { e }\end{array}$ & $\begin{array}{l}\text { Lower } \\
\text { Limit }\end{array}$ & $\begin{array}{l}\text { Upper } \\
\text { Limit }\end{array}$ & $\mathbf{z}$ & $\mathbf{p}$ \\
\hline Primary School & & & & & & & & & \\
\hline Fixed Effects Model & 2 & -0.202 & 8.175 & 0.186 & 0.035 & -0.567 & 0.163 & -1.086 & 0.000 \\
\hline $\begin{array}{l}\text { Random Effects } \\
\text { Model }\end{array}$ & 2 & -0.245 & 8.175 & 0.535 & 0.286 & -1.293 & 0.803 & -0.458 & 0.000 \\
\hline $\begin{array}{l}\text { Middle School } \\
\text { Fixed Effects Model }\end{array}$ & 11 & 0.576 & 6.183 & 0.075 & 0.006 & 0.430 & 0.723 & 7.705 & 0.000 \\
\hline
\end{tabular}

As can be seen in Table 25, the overall effect size of student-centered methods on mathematics anxiety for primary school was found to be $-0.245(\mathrm{z}=-0.458, \mathrm{p}<0.05)$. At the $95 \%$ confidence interval, the lower limit was found to be -1.293 and the upper limit was 0.803 . The overall effect size corresponds to the insignificant effect size level. As for middle school, the overall effect size on mathematics anxiety was obtained as $0.576(\mathrm{z}=7.705, \mathrm{p}$ $<0.05)$. The lower limit of the overall effect size is 0.430 and the upper limit is 0.723 . The overall effect size corresponds to the medium effect size level.

\section{Conclusion and Discussion}

This research aimed to study a variety of research investigating the effects on mathematics attitude, anxiety and success of the student centered methods like the problem solving method, project management, computer-assisted teaching method, cooperative learning, learning based on multiple intelligence theory, drama method, educational games technique, concept cartoons technique. The subject matter research is on the effect of studentcentered teaching methods on mathematics teaching, and this study sought primarily for the overall effect sizes of those studies. While analyzing the overall effect size, the "metaanalysis" method was used. Thanks to it, the combined effect of the studies carried out for the same purpose in different samples could be revealed. So, it is a comprehensive study 
conducted on 54 studies examining the effect of student-centered methods on mathematics achievement, 42 studies on attitude towards mathematics and 15 studies on anxiety towards it. The overall effect size of the studies was calculated both as a whole and for each level of education individually. Findings of this meta-analysis indicate that the overall effect size of student-centered teaching methods on mathematics achievement is large and meaningful in terms of the classification made by Cohen and his friends. It can be concluded that those student centered methods are quite effective on mathematics achievement compared to the teacher centered ones. These findings reveal the effectiveness of the investigated methods, regardless of the levels of education. The effect of student-centered methods on the affective dimensions like attitude and anxiety, which affect success, is also important. Although their numbers are not very high, there are some studies on the effects of methods on affective dimensions in the literature. The scarcity of studies especially on method and mathematics anxiety draws attention. The overall effect size of student-centered methods on attitude towards mathematics was found to be medium and meaningful according to the effect size classification. In the examinations carried out on attitude individually for primary, middle and high school levels, it has been observed that the studies examined have medium effect size level, too. When the studies with different samples are synthesized, the findings indicate that student-centered methods have an undeniable impact on an important affective feature such as attitude, which changes over time and which is an essential factor effecting learning.

When the studies on anxiety were analyzed, it was seen that the student-centered methods examined within the scope of the research had a medium overall effect size on mathematics anxiety, and that the overall effect level was insignificant for primary school while it was medium for middle school. The fact that only two studies were accessed for primary school has been a limiting factor in interpreting the overall effect. The study has shown that studentcentered methods have a role in reducing mathematics anxiety, although they do not have a wide impact. Another result of the study is that while there are a lot of studies in the literature examining the effects of aforementioned methods on student achievement at all levels, there are only a few studies on anxiety, one of the crucial factors in teaching. While designing this research, only the studies with control and experimental groups were included to attain systematicity. It is contended here that if the effect sizes are calculated for also single-group studies along with correlational and proportional data, a richer set of data can be obtained about the effectiveness of student-centered methods. Although the researcher's intention was to cover higher education level, there was no sufficient number of research at that level to include in this study. In order to get information at every level, perhaps longitudinally, studies examining the effect of student-centered methods on mathematics teaching in higher education can be increased. Since this meta-analysis covers only the research conducted in Turkish language, a further study can be carried on international level with a focus on comparative results. By conducting meta-analysis studies on the effect of student-centered methods used in mathematics on self-efficacy and problem solving, more information can be obtained in the field of mathematics and mathematics education. While investigating the general effect of student-centered methods on mathematics achievement, attitude and on anxiety, future studies can be conducted with a focus on learning areas along with educational levels.

\section{Acknowledgements}

This study was based on Elif Ay Emanet's master thesis titled " The effects of student-centered teaching methods used in mathematics courses on mathematics achievement, attitude and anxiety: a meta-analysis study" (2019), at Kocaeli University Institute of Social Sciences. 


\section{References}

Altun, M. (2001). Ilköğretim ikinci kademede matematik öğretimi [Teaching mathematics in the second grade of primary education]. Bursa: Alfa Yayınları.

Altun, M. (2009). Ĕ̈itim fakülteleri ve lise matematik ögretmenleri için liselerde matematik ögretimi [Teaching mathematics in high schools for education faculties and high school mathematics teachers]. Bursa: Alfa Yayınlar1.

Bakioğlu, A., \& Şafak Ö. (2016). Meta-analiz [Meta-Analysis]. Ankara: Nobel Yayınc1lık.

Baykul, Y. (2003). Ilkögretimde matematik öğretimi [Teaching mathematics in primary education ]. $7^{\text {th }}$ ed. Ankara: Pegem A Yayıncilik.

Baysal, A. (1981). Sosyal ve örgütsel psikolojide tutumlar [Attitudes in social and organizational psychology]. İstanbul: Yalkın Ofset Matbaa.

Borenstein, M., Hedges, L.V., Higgins, J.P., \& Rothstein, H.R. (2009). Introduction metaanalysis. UK: John Wiley \& Sons, Ltd.

Bukova Güzel, E. (2016). Matematik ĕgitiminde matematiksel modelleme [Mathematical modelling in mathematics education]. Ankara: Pegem Akademi.

Card, N.A. (2011). Applied meta-analysis for social science research. New York, London: The Guilford Press.

Coe, R.J. (2017). "Etki büyüklüğü [Effect size]” Ed. Arthur, James, Michael Waring, Robert Coe, Larry V. Hedges. Eğitimde araştırma yöntemleri ve metodolojileri [Research methods and methodologies in education]. (Çev. Ed. Atılgan Erözkan, Engin Büyüköksüz). Ankara: Anı Yayıncılık.

Cohen, R. J., \& Swerdlik, M.E. (2013). Psychological testing and assesment: An introduction to tests and measurement. USA: The McGraw-Hill Companies.

Çelebi Yıldız, N. (2002). Verilerin değerlendirilmesinde meta-analizi [Meta-analysis in evaluating data]. (Unpublished master dissertation). Marmara University Institute of Science, İstanbul.

Demirtaş Madran, H. A. (2012). Tutum, tutum değişimi ve ikna [Attitude, attitude change and persuasion]. Ankara: Nobel Yayınc1lık.

Dinçer, S.(2014). Eğitim bilimlerinde uygulamalı meta-analiz [Applied meta-analysis in educational sciences]. Ankara: Pegem Akademi.

Hacısalihoğlu, H. H., Mirasyedioğlu, Ş., \& Akpınar, A. (2003). Illköğretim 1-5 matematik ögretimi [Primary 1-5 mathematics teaching]. Ankara: Asil Yayın Dağıtım.

İnceoğlu, M. (2000). Tutum, algl, iletişim [Attitude, perception, communication]. Ankara: İmaj Yayınevi.

Kocayörük, E., \& Çelik, B. (2009). Öğrenme [Learning]. In Neriman Aral \& Tayyip Duman (Ed.), Eğitim psikolojisi [Educational Pyschology]. İstanbul: Kriter Yayıncılık.

Kretch, D., Crutchfield, R. S., \& Ballachey, E.L. (1962). Individual in society. London: McGraw- Hill.

Lipsey, M. W., \& David B. W. (2000). Practical meta-analysis. London: Sage Publications.

Morgan, T. C. (2011). Psikolojiye giriş [Introduction to psycology]. 19 ${ }^{\text {th }}$ ed. (Çev. Sirel Karakaş ve Rükzan Eski). Konya: Eğitim Akademi Yayınları.

Olkin, I. (1999). Diagnostic statistical procedures in medical meta-analysis. Stat-Med, 18, 2331-2341.

Özgüven, İ. E. (2015). Psikolojik testler [Psychological Tests]. Thirteenth Edition. Ankara: Nobel Yayıncilik.

Senemoğlu, N. (2002). Gelişim, ögrenme ve öğretim kuramdan uygulamaya [Development, learning and teaching from theory to practice]. Ankara: Gazi Kitabevi. 
Tavşancıl, E. (2014). Tutumların ölçülmesi ve spss ile veri analizi [Measuring attitudes and data analysis with spss]. $5^{\text {th }}$ ed. Ankara: Nobel Yayınc1lik.

Tekindal, S. (2015). Duyuşsal özelliklerin ölçülmesi için araç oluşturma [Creating a tool for measuring affective characteristics]. $3^{\text {rd }}$ ed. Ankara: Pegem Akademi.

Thurstone, L. L. (1928). Attitudes can be measured. American Journal of Sociology, 33 (4), 529-554.

Topan, B. (2013). Matematik öğretiminde öğrenci merkezli yöntemlerin akademik başarı ve derse yönelik tutum üzerindeki etkililiği: bir meta-analiz çalışması [The effectiveness of student-centered methods in mathematics teaching on academic achievement and attitude towards the lesson: a meta-analysis study.]. (Unpublished master dissertation). Kocaeli University Institute of Social Sciences, Kocaeli.

Van De Walle, J.A, Karp, K.S,\& BayWillams, J.M. (2016). Ilkokul ve ortaokul matematiği, gelişimsel yaklaşımla ögretim [ Primary and secondary school mathematics, teaching with a developmental approach] (Çev. S. Durmuş). Ankara: Nobel Yayıncılık.

Westcott, A., \& Smith, J. (1978). Creative teaching of mathematics in the elementary school. Boston: Allyn and Bacon.

Yenilmez, K., \& Özbey, N. (2006). Özel okul ve devlet okulu öğrencilerinin matematik kayg1 düzeyleri üzerine bir araştırma [A study on the math anxiety levels of private and public school students]. Journal of Uludağ University Faculty of Education, 19 (2), 431- 448.

Yücel, Z., \& Koç, M. (2011). Investigation of the Anxieties and Attitudes of Elementary School Students Towards Mathematics with Various Variables. Elementary Education Online, 10(1), 133-143. 